\title{
Interpretation of serum total calcium: effects of adjustment for albumin concentration on frequency of abnormal values and on detection of change in the individual
}

\author{
R. B. PAYNE, MARGARET E. CARVER, AND D. B. MORGAN \\ From the Department of Chemical Pathology, St James's University Hospital, Leeds LS9 7TF and the \\ University Department of Chemical Pathology, General Infirmary, Leeds LS1 3EX, UK
}

SUMMARY Serum total calcium was measured in 1693 patients during a four-month period. We examined the effects of adjustment for albumin concentration on the interpretation of single measurements of serum total calcium and on the variation of series of measurements in individual patients.

Markedly abnormal total calcium concentrations $-2.75 \mathrm{mmol} / 1(11.0 \mathrm{mg} / 100 \mathrm{ml})$ or more, or $2.00 \mathrm{mmol} / 1(8.0 \mathrm{mg} / 100 \mathrm{ml})$ or less-were found in 115 patients, but only $24(21 \%)$ remained markedly abnormal after adjustment for albumin. Three patients, two with malignant disease and one with primary hyperparathyroidism, had significant hypercalcaemia which was masked by hypoalbuminaemia. The serum total calcium measured on a subsequent occasion had changed $0 \cdot 15$ $\mathrm{mmol} / 1(0.6 \mathrm{mg} / 100 \mathrm{ml})$ or more in 60 patients, but after adjustment for albumin this number was reduced to $27(45 \%)$. The within-person standard deviation for serum total calcium was calculated in 26 patients with normal mean adjusted calcium concentrations who had had six or more sequential measurements. The mean standard deviation was $0.148 \mathrm{mmol} / 1(0.59 \mathrm{mg} / 100 \mathrm{ml})$ and, after adjustment for albumin, this was reduced to $0.100 \mathrm{mmol} / 1(0.40 \mathrm{mg} / 100 \mathrm{ml})$.

We conclude that adjustment of serum total calcium concentration for albumin is essential to detect abnormal values and to assess changes in a value.

About half the calcium in serum is bound to serum proteins, particularly albumin. Changes in protein concentration alone cause changes in total calcium without affecting the physiologically and clinically important ionised calcium fraction (British Medical Journal, 1977). We have investigated the prevalence of clinically misleading serum total calcium concentration in 1693 patients who had calcium and albumin measured at least once in a four-month period.

\section{Patients and methods}

Serum total calcium and albumin were measured by standard methods on a Technicon SMA Plus in the Department of Chemical Pathology at St James's University Hospital. They were part of a 'bone and

Received for publication 15 June 1978 liver profile' which included total protein, phosphate, bilirubin, alkaline phosphatase, and alanine transaminase. The analytical coefficients of variation were about $2 \%$ for calcium and about $3 \%$ for albumin at normal serum concentrations, and the reference ranges determined immediately before this investigation were $2 \cdot 20-2 \cdot 60 \mathrm{mmol} / 1(8 \cdot 8-10 \cdot 4 \mathrm{mg} / 100 \mathrm{ml})$ for calcium and $35-47 \mathrm{~g} / 1(3 \cdot 5-4 \cdot 7 \mathrm{~g} / 100 \mathrm{ml})$ for albumin (Little et al., 1974).

We examined the patient report cards for the period January to April 1974. We excluded patients aged 16 years or less and patients from the Department of Renal Medicine. A total of 1693 patients had had specimens analysed for calcium and albumin on at least one occasion. The serum total calcium concentrations were adjusted for albumin using the equation derived in the same laboratory (Payne et al., 1973):

adjusted calcium $(\mathrm{mmol} / \mathrm{l})=$ calcium $(\mathrm{mmol} / \mathrm{l})-$ 0.025 albumin $(\mathrm{g} / \mathrm{l})+1.0$ 
(adjusted calcium $(\mathrm{mg} / 100 \mathrm{ml})=$ calcium $(\mathrm{mg} / 100$ $\mathrm{ml})-\operatorname{albumin}(\mathrm{g} / 100 \mathrm{ml})+4 \cdot 0)$

The equation in SI units can be written in a form more convenient for mental arithmetic:

adjusted calcium $=$ measured calcium $+(40-$ albumin)/40.

(The regression coefficient of calcium on albumin for patients has been determined, as previously described (Payne et al., 1973) on two further occasions during the last four years and has not differed significantly.)

We studied two groups of patients: 115 patients who had markedly abnormal serum total calcium concentrations $\leqslant 2.00 \mathrm{mmol} / 1(8.0 \mathrm{mg} / 100 \mathrm{ml})$ or $\geqslant$ $2.75 \mathrm{mmol} / 1(11.0 \mathrm{mg} / 100 \mathrm{ml}))$; and 74 patients who had normal serum total calcium concentrations of $2 \cdot 20-2 \cdot 60 \mathrm{mmol} / 1(8 \cdot 8-10 \cdot 4 \mathrm{mg} / 100 \mathrm{ml})$, which became abnormal on adjustment for albumin. We examined the case notes of the two groups of patients (when they were available) and recorded relevant clinical features and laboratory data. In the former group, there were 60 patients with a significant difference between calcium concentrations measured on separate occasions $(\geqslant 0.15 \mathrm{mmol} / 1$; $0.6 \mathrm{mg} / 100 \mathrm{ml}$ ), and 26 patients with a normal mean adjusted calcium concentration who had had six or more sequential measurements.

\section{Results}

\section{CROSS-SECTIONAL STUDIES OF CALCIUM CONCENTRATION}

Of the 1693 patients who had calcium measured, 115 $(6.8 \%)$ had very abnormal total calcium concentrations: 93 were $2.00 \mathrm{mmol} / 1$ or less and 22 were 2.75 $\mathrm{mmol} / 1$ or more. After adjustment of total calcium for albumin concentration only 12 had values of $2.00 \mathrm{mmol} / 1$ or less and only 12 of $2.75 \mathrm{mmol} / 1$ or more (Table 1). In 63 of the 93 patients with very low total calcium values, the plasma calcium was within the normal range after adjustment.

The measurements had been repeated and confirmed in 11 of the 12 patients who had a total calcium of $2.00 \mathrm{mmol} / 1$ or less after adjustment for albumin. Four had chronic renal disease and two had proven bone disease which was treated. However, in the remaining five (with principal diagnoses of cor pulmonale due to chronic bronchitis, chronic pancreatitis, carcinoma of the bowel, hypertension, and myxoedema respectively) there is no record of any further action having been taken.

Two of the 12 patients with total calcium values that remained $2.75 \mathrm{mmol} / \mathrm{l}$ or more after adjustment (with principal diagnoses of lymphoedema and of empyema of the gall-bladder) were not investigated further. In one of them this appeared to be because the laboratory report had not reached the case notes. Of the remaining 10 patients with marked hypercalcaemia, seven had carcinomatosis ( 5 of the breast, 1 of the ovary, 1 of the pancreas) and three had primary hyperparathyroidism.

In 74 patients $(4.4 \%$ of the total) normal total calcium concentrations became abnormal after adjustment for albumin. Most of the adjusted values were only marginally outside the reference range. None adjusted as low as $2.00 \mathrm{mmol} / \mathrm{l}$, but six adjusted to $2.75 \mathrm{mmol} / \mathrm{l}$ or more. Case notes were available for five of these six patients. In two it was clear from sequential data that the reported albumin concentration was erroneously low. Two of the other three patients had a strong clinical suspicion of disseminated malignancy, and one had severe liver disease and primary hyperparathyroidism. All three died shortly after the index measurement had been made.

\section{CHANGES OF TOTAL CALCIUM}

CONCENTRATION WITH TIME

The between-batch analytical SD was $0.05 \mathrm{mmol} / \mathrm{l}$ $(0.2 \mathrm{mg} / 100 \mathrm{ml})$ so that a difference in total serum calcium between two samples of $0.15 \mathrm{mmol} / 1(0.6$ $\mathrm{mg} / 100 \mathrm{ml}$ ) or more was unlikely at $\mathrm{P}<0.05$ (Campbell and Owen, 1967) to be due to analytical factors alone. Specimens from 60 of the patients with markedly abnormal serum total calcium concentrations showed a difference between measurements made on separate occasions of at least this magnitude. After allowance had been made for changes in albumin concentration the difference between the two adjusted calcium measurements

Table 1 Distribution of serum calcium concentrations after adjustment for albumin in 115 patients with markedly abnormal calcium concentrations before adjustment

\begin{tabular}{|c|c|c|c|}
\hline \multicolumn{2}{|c|}{ Serum total calcium $2.00 \mathrm{mmol} / \mathrm{l}$ or less } & \multicolumn{2}{|c|}{ Serum total calcium 2.75 mmolll or more } \\
\hline Adjusted calcium (mmolll) & No. $(\%)$ & Adjusted calcium (mmol/l) & No. $(\%)$ \\
\hline $\begin{array}{l}2 \cdot 20-2 \cdot 60 \\
2 \cdot 01-2 \cdot 19 \\
\leqslant 2 \cdot 00 \\
\text { Total }\end{array}$ & $\begin{array}{l}63(68) \\
18(19) \\
12(13) \\
93(100)\end{array}$ & $\begin{aligned} & 2 \cdot 20-2 \cdot 60 \\
& 2 \cdot 61-2 \cdot 74 \\
\geqslant & 2 \cdot 75\end{aligned}$ & $\begin{array}{c}4(18) \\
6(27) \\
12(55) \\
22(100)\end{array}$ \\
\hline
\end{tabular}

Conversion: SI to traditional units-Serum calcium: $1 \mathrm{mmol} / 1 \approx 4 \mathrm{mg} / 100 \mathrm{ml}$ 
remained $0.15 \mathrm{mmol} / \mathrm{l}$ or more in only $27(45 \%)$ of the 60 patients.

There were 26 patients with at least one serum total calcium concentration of $2.00 \mathrm{mmol} / 1$ or less, who had had six or more consecutive measurements, and in whom the mean adjusted calcium concentration was within the reference range $(2 \cdot 20-2 \cdot 60$ $\mathrm{mmol} / \mathrm{l})$. The SD was calculated for each patient's set of data for calcium and for calcium adjusted for albumin.

When the serum calcium was adjusted for albumin there was a significant reduction in the withinpatient SD values (mean $32 \%$ ) and in the range of values (Table 2).

Examples of sequential data from patients who showed changes in calcium which could and could not be attributed to changes in albumin are shown in the Figure.

\section{Discussion}

Before some of the issues raised by this work are discussed, it is worth noting that we have deliberately chosen the term 'adjusted calcium' to describe the mathematical allowance made for the effect of protein concentration on total serum calcium. We prefer to retain the term 'corrected calcium' for situations where the (ionised) calcium concentration has returned to normal after medical or surgical intervention.

The physiologically and clinically important fraction of the serum total calcium is the ionised calcium, and there can be no dispute that accurate and precise measurement of the ionised calcium would be the ideal. Unfortunately, this measurement is technically complex and requires the rapid analysis of an anaerobic blood sample. A screening procedure is therefore still required to make allowance for effect of changes in protein concentration on the interpretation of serum total calcium (Dent, 1962; Payne et al., 1973). The procedure does not allow for changes in ionised calcium due to in vivo changes in $\mathrm{pH}$ but it is, of course, unaffected by in vitro changes in $\mathrm{pH}$.

Table 2 Mean and $S D$ of within-patient $S D$ for serum calcium in 26 patients with low serum albumin, normal adjusted serum total calcium, and at least six sequential observations

\begin{tabular}{lll}
\hline & $\begin{array}{l}\text { Mean } \\
(\mathrm{mmol} / \mathrm{l})\end{array}$ & $\begin{array}{l}\text { Standard deviation } \\
(\mathrm{mmol} / \mathrm{l})\end{array}$ \\
\hline $\begin{array}{l}\text { Within-patient SD of calcium } \\
\begin{array}{l}\text { Within-patient SD of calcium } \\
\text { adjusted for albumin }\end{array}\end{array}$ & 0.148 & 0.058 \\
\hline
\end{tabular}

Paired $t=5.75, \mathrm{P}<0.001 ; \mathrm{F}=3.09, \mathrm{P}<0.01$

Conversion: SI to traditional units-Serum calcium: $1 \mathrm{mmol} / 1 \approx$ $4 \mathrm{mg} / 100 \mathrm{ml}$

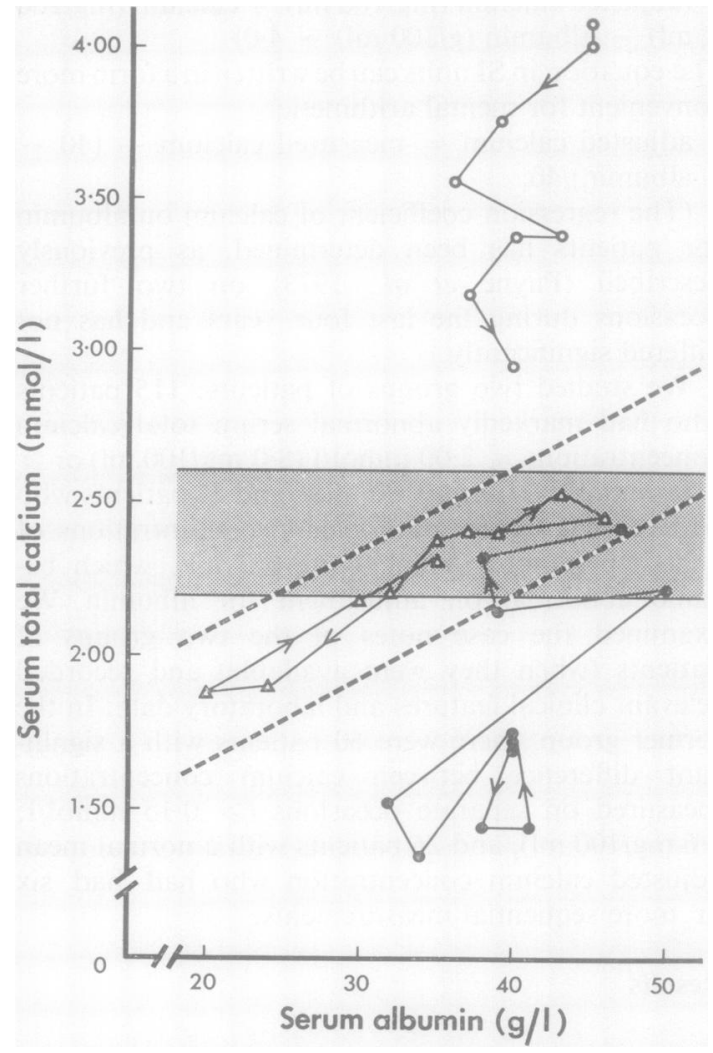

Figure Sequential serum total calcium and serum albumin concentrations in three patients. The shaded area indicates the reference range for serum total calcium, and the dashed lines encompass the values that give normal adjusted calcium concentrations: $\bigcirc-\bigcirc$ treatment for hypercalcaemia due to carcinomatosis; - treatment for hypocalcaemia due to osteomalacia; $\triangle-\triangle$ chronic active hepatitis with changes in calcium concentration due to spontaneous changes in albumin.

Conversion: SI to traditional units-Serum calcium: $1 \mathrm{mmol} / 1 \approx 4 \mathrm{mg} / 100 \mathrm{ml}$.

We have chosen to adjust serum total calcium for albumin rather than for total protein because the latter adjustment is inaccurate when the distribution of serum proteins is abnormal (Dent and Watson, 1968), and it is particularly inaccurate in hypergammaglobulinaemia, which is usually the most marked globulin abnormality in patients with reduced serum albumin (Payne et al., 1973). In any case, less than $8 \%$ of the serum total calcium is bound to globulins, and there is negligible binding to gammaglobulin in hypergammaglobulinaemia (Pederson, 1972a).

The use of albumin measured by bromocresol 
green (BCG) methods to adjust calcium has been criticised on the grounds that, by comparison with specific immunochemical methods, the method overestimates albumin concentrations when they are low because the dye is bound by the commonly increased amounts of $\alpha$ - and $\beta$-globulins (Webster, 1976). However, the data on which this criticism is based (Webster et al., 1974) showed a close linear relationship ( $r=0.97$ ) between albumin measured by BCG and by specific immunological methods over the range $5-48 \mathrm{~g} / 1(0 \cdot 5-4 \cdot 8 \mathrm{~g} / 100 \mathrm{ml})$. A similarly close relationship $(r=0.986)$ has been reported independently in 160 sera with a wide range of albumin concentrations (Pinnell and Northam, 1978). As there is a close linear relationship between the values, whatever the position and slope of that relationship, any of the albumin methods can be used for the adjustment of total calcium if the same method is used both to define and to make the adjustment. The equation we have used here is valid for albumin measured by BCG.

The use of an average regression coefficient has been criticised because it has been argued - correctly - that patients with high or low ionised calcium concentrations would have higher or lower regression coefficients (Marshall and Nordin, 1974; Parfitt, 1974). However, the adjustment we have used gives values that are higher than they should be when ionised calcium is high, and lower when it is low, and it thus fulfills its intended function as a screening procedure (Payne et al., 1974).

It has also been argued that the use of an average regression coefficient is inappropriate because tourniquet and posture experiments show that there are significant differences even between normal individuals in the regressions of calcium on albumin (Pain et al., 1975). The original work was strongly criticised on statistical grounds (Hodkinson, 1976; Payne et al., 1976; Ramsay and Shelton, 1976), but the same authors tested further tourniquet data by analysis of variance and reported a significant component due to differences between individual regression coefficients (Phillips et al., 1977). This has been confirmed in Leeds (B. E. Walker and R. B. Payne, in preparation). We suggest that there are good grounds for using a common regression coefficient that has been derived from patients with normal and low albumin concentrations but with no clinical suspicion of a disturbance of calcium homeostasis in order to adjust values in patients with low albumin who are suspected to have calcium disturbances. However, the single coefficient will not make an appropriate adjustment for the variable changes that may follow venous stasis, and it is therefore still important to take the blood samples with a free flow technique.
A striking feature of the present work is that while $93(5.5 \%)$ of 1693 patients during a four-month period had serum total calcium concentrations of $2.00 \mathrm{mmol} / \mathrm{l}$ or less, as many as $63(68 \%)$ of the 93 low values could be attributed to low albumin concentrations.

The data we have examined came from patients in whom the clinical question was usually either about liver function or calcium homeostasis, but it was not always possible to distinguish the purpose of the request from the record card. However, in an earlier study, in which the requests could be readily distinguished, we found that 22 of 100 consecutive patients specifically investigated for disturbances of calcium metabolism had reduced total calcium concentrations, and in $13(59 \%)$ of the 22 this could be attributed to low albumin values (Payne et al., 1973). Thus, low albumin values make a very significant contribution to the occurrence and interpretation of low calcium values not only in 'profile' studies but also in specific investigations for calcium disturbances.

Both studies of the changes of total calcium with time reported here showed that variability in serum total calcium within individual patients was significantly reduced by taking account of variability in albumin concentration. Of 60 patients with paired analyses that showed a significant non-analytical change in calcium concentration, the change could be attributed to a change in albumin concentration in $33(55 \%)$; and the within-patient SD for calcium was reduced in all but three of 26 patients when account was taken of albumin concentration. These reductions in variability are the more striking because the values for adjusted calcium concentration are based on independent single measurements of calcium and albumin, each of which has its own analytical error. It should be noted that our withinpatient SD is based on data acquired over variable periods and at variable intervals and cannot therefore be compared with standardised studies on within-person variability in normals (Pedersen, 1972b; Winkel et al., 1974; Winkel et al., 1975; Pickup et al., 1977).

The examples of sequential data for serum total calcium and albumin (Figure) show some interesting features. The patient with carcinomatosis had a true hypercalcaemia, which responded to therapy. But nevertheless much of the fall in calcium concentration between the second and fourth points is due to a change in albumin concentration, since its direction approaches the slope of the 'normal' regression of calcium on albumin. Similarly, the biggest stepwise increase in total calcium in the patient treated for osteomalacia (between the seventh and eighth points) is largely due to a change in albumin. In the patient 
with chronic active hepatitis, almost the whole of the variation in total calcium concentration between 1.87 and $2.47 \mathrm{mmol} / 1(7.5-9.9 \mathrm{mg} / 100 \mathrm{ml})$ is due to spontaneous changes in albumin concentration, the lines lying nearly parallel to the 'normal' regression.

We conclude that the interpretation of patients' serum total calcium values will often be misleading unless some allowance is made for albumin concentration, and that patients' results are more reproducible when this is done. It is difficult to see how a laboratory can any longer justify the measurement of serum total calcium without measuring the serum albumin on the same specimen and adjusting the serum calcium for the albumin.

We are grateful to the clinicians at St James's University Hospital for permission to examine the case-notes of their patients. This work was supported by a grant from the West Riding Medical Research Trust.

\section{References}

British Medical Journal. (1977). Correcting the calcium (Leading article). British Medical Journal, 1, 598.

Campbell, D. G., and Owen, J. A. (1967). Clinical laboratory error in perspective. Clinical Biochemistry, 1, 3-11.

Dent, C. E. (1962). Some problems of hyperparathyroidism. British Medical Journal, 2, 1419-1425.

Dent, C. E., and Watson, L. (1968). The hydrocortisone test in primary and tertiary hyperparathyroidism. Lancet, 2, 662-664.

Hodkinson, H. M. (1976). "Corrected" calcium concept (Letter). British Medical Journal, 1, 219-220.

Little, A. J., Williams, R. B., Parker, S. D., and Payne, R. B. (1974). The derivation of biochemical normal ranges from a hospital outpatient population. Clinica Chimica Acta, 57, 91-95.

Marshall, R. W., and Nordin, B. E. C. (1974). Adjustment of plasma calcium measurements (Letter). British Medical Journal, 2, 729-730.

Pain, R. W., Rowland, K. M., Phillips, P. J., and Duncan, B. McL. (1975). Current "corrected" calcium concept challenged. British Medical Journal, 4, 617-619.

Parfitt, A. M. (1974). Correction of plasma calcium measurements (Letter). British Medical Journal, 1, 520.

Payne, R. B., Little, A. J., Williams, R. B., and Milner, J. R. (1973). Interpretation of serum calcium in patients with abnormal serum proteins. British Medical
Journal, 4, 643-646.

Payne, R. B., Little, A. J., Williams, R. B., and Milner, J. R. (1974). Adjustment of plasma calcium measurements (Letter). British Medical Journal, 3, 345.

Payne, R. B., Little, A. J., Williams, R. B., and Milner, J. R. (1976). "Corrected" calcium concept (Letter). British Medical Journal, 1, 153-154.

Pedersen, K. O. (1972a). Protein-bound calcium in human serum. Quantitative examination of binding and its variables by a molecular binding model and clinical chemical implications for measurement of ionized calcium. Scandinavian Journal of Clinical and Laboratory Investigation, 30, 321-329.

Pedersen, K. O. (1972b). On the cause and degree of intraindividual serum calcium variability. Scandinavian Journal of Clinical and Laboratory Investigation, 30, 191-199.

Phillips, P. J., Pain, R. W., Hartley, T. F., Duncan, B. McL., and Atkinson, M. J. (1977). Current "corrected" calcium concept rechallenged (Letter). Clinical Chemistry, 23, 1938-1939.

Pickup, J. F., Harris, E. K., Kearns, M., and Brown, S. S. (1977). Intraindividual variation of some serum constituents and its relevance to population-based reference ranges. Clinical Chemistry, 23, 842-850.

Pinnell, A. E., and Northam, B. E. (1978). New automated dye-binding method for serum albumin determination with bromcresol purple. Clinical Chemistry, 24, 80-86.

Ramsay, L. E., and Shelton, J. R. (1976). "Corrected" calcium concept (Letter). British Medical Journal, 1, 219.

Webster, D. (1976). “Corrected” calcium concept (Letter). British Medical Journal, 1, 154.

Webster, D., Bignell, A. H. C., and Attwood, E. C. (1974) An assessment of the suitability of bromcresol green for the determination of serum albumin. Clinica Chimica Acta, 53, 101-108.

Winkel, P., Statland, B. E., and Bokelund, H. (1974). Factors contributing to intra-individual variation of serum constituents 5. Short-term day-to-day and within-hour variation of serum constituents in healthy subjects. Clinical Chemistry, 20, 1520-1527.

Winkel, P., Statland, B. E., Bokelund, H., and Johnson, E. A. (1975). Correlation of selected serum constituents 1. Inter-individual variation and analytical error. Clinical Chemistry, 21, 1592-1600.

Requests for reprints to: Dr R. B. Payne, Department of Chemical Pathology, St James's University Hospital, Beckett Street, Leeds LS9 7TF. 